\title{
PENGEMBANGAN BAHAN AJAR BERBASIS MULTIPLE INTELLIGENCES UNTUK MENINGKATKAN KEMAMPUAN BERPIKIR KRITIS
}

\section{DEVELOPING TEACHING MATERIAL BASED ON MULTIPLE INTELLIGENCES TO IMPROVE THE CRITICAL THINKING ABILITY}

\author{
St. Hartina Anwar1), Muhammad Rusydi Rasyid2), Suharti ${ }^{3)}$, Sri Sulasteri ${ }^{4)}$ \\ 1,2,3,4) Fakultas Tarbiyah dan Keguruan Universitas Islam Negeri Alauddin Makassar \\ st.hartinaanwar@gmail.com ${ }^{1}$, muhammadrusydi@uin-alauddin.ac.id ${ }^{2}$ ), suharti.harti@uin- \\ alauddin.ac.id ${ }^{3)}$, sri.sulasteri@uin-alauddin.ac.id( ${ }^{4)}$
}

\begin{abstract}
Abstrak
Penelitian ini bertujuan untuk mengembangkan bahan ajar berupa buku ajar matematika berbasis multiple intelligences pada materi trigonometri untuk meningkatkan kemampuan berpikir kritis siswa kelas X SMAN 3 Wajo dan mengetahui tingkat kevalidan, kepraktisan, dan keefetifannya. Jenis penelitian yang digunakan adalah Research \& Development dengan mengacu pada model 4D yang terdiri dari Define, Design, Development dan Dissseminate. Produk yang dikembangkan berupa buku ajar berbasis multiple intelligences pada materi trigonometri yang diantaranya terdiri dari beberapa aspek multiple intelligences yaitu logis-matematis, visual-spasial, linguistik-verbal, interpersonal dan intrapersonal. Berdasarkan hasil ujicoba terbatas yang dilakukan, diperoleh bahwa (1) Buku ajar berbasis multiple intelligences dikembangkan dengan menggunakan model pengembangan 4D (define, design, development, dan disseminate), (2) Bahan ajar valid berdasarkan ratarata penilaian hasil validasi buku ajar beserta instrumen lainnya adalah 4,17 dengan kategori sangat valid, (3) Praktis karena persentase rerata untuk respons siswa adalah $81,25 \%$ pada kategori positif dan persentase rerata respons guru adalah $92,50 \%$ pada kategori sangat positif, (4) Efektif karena rerata kemampuan guru dalam mengelola pembelajaran ialah 4,28 berada pada kategori baik, persentase rata-rata aktivitas siswa adalah $64,53 \%$ berada pada kategori baik, dan persentase ketuntasan belajar siswa berada pada kategori tinggi yaitu $80,65 \%$. Sehingga pengembangan bahan ajar berbasis multiple intelligences pada materi trigonometri di kelas X SMAN 3 Wajo sudah memenuhi kriteria kevalidan, kepraktisan, dan keefektifan.
\end{abstract}

Kata Kunci: bahan ajar, multiple intelligences, berpikir kritis

\begin{abstract}
The study aims to develop teaching material in the form of mathematics textbook based on multiple intelligences in trigonometry material to improve critical thinking ability of class $X$ students of SMAN 3 Wajo and to determine the level of validity, practicality, and effectiveness. The type of research used is Research and Development with reference to the 4D model which consists of Define, Design, Development, and Disseminate. The product developed is a textbook based on multiple intelligences on trigonometric material which includes several aspects of multiple intelligences, namely logical mathematical, visualspatial, linguistic-verbal, interpersonal and intrapersonal. Based on the result of limited trials conducted, it was found that (1) Multiple intelligences based textbook were developed using the 4D development model (define, design, development, and disseminate), (2) Valid based on the average assessment of the validation results of the textbooks and other instruments is 4.17 in the very valid category, (3) Practical because the average percentage of student responses is $81.25 \%$ in the positive category and the average percentage of teacher response is $92.50 \%$ in the very positive category, (4) Effective because the teacher's
\end{abstract}


average ability in managing learning is 4.28 in the good category, the average percentage of student activity is $64.43 \%$ in the good category, and percentage of student learning completeness is in the high category, namely $80.65 \%$. So, the development of teaching material based on multiple intelligences on trigonometric material in class X SMAN 3 Wajo has met the criteria of validity, practicality, and effectiveness.

Keywords: teaching material, multiple intelligences, critical thinking

How to Cite: Anwar, S. H., Rasyid, M. R., Suharti \& Sulasteri, S. (2020). Pengembangan bahan ajar berbasis multiple intelligences untuk meningkatkan kemampuan berpikir kritis. Al asma: Journal of Islamic Education, 2(2), 170-180.

\section{PENDAHULUAN}

Suatu proses untuk mengembangkan aspek-aspek kepribadian manusia mencakup nilai, pengetahuan dan sikap, serta keterampilan dinamakan proses pendidikan. Pendidikan dijalani untuk mencapai kepribadian seseorang yang lebih baik (Sadulloh, 2015). Pendidikan sebagai usaha yang secara sengaja dirancang guna membantu individu maupun masyarakat mengembangkan pandangan hidup, ilmu pengetahuan, keterampilan hidup, dan sikap baik yang bersifat manual individual atau sosial. Sebagai fenomena atau peristiwa perjumpaan antara dua orang atau lebih, pendidikan memberikan dampak dalam perkembangan suatu pandangan hidup, keterampilan, dan sikap hidup kepada salah satu atau beberapa pihak (Sagala, 2013).

Perkembangan ilmu pengetahuan dan teknologi (IPTEK) telah berdampak dalam semua garis kehidupan. Perkembangan dan perubahan dunia terjadi dengan cepat. Karenanya diperlukan kemampuan untuk memperoleh, mengelola dan memanfaatkan IPTEK tersebut secara maksimal. Kemampuan ini memerlukan pemikiran yang kritis, logis dan sistematis yang bisa dikembangkan melalui peningkatan mutu pendidikan. Hal yang paling menentukan dalam ketercapaian pendidikan dengan mutu yang berkualitas adalah proses pembelajaran yang dilaksanakan (Sundayana, 2013). Proses pembelajaran dapat diubah dari sistem pembelajaran konvensional ke pembelajaran berbasis teknologi. Pemanfaatan teknologi dalam pembelajaran mampu mendorong kualitas pendidikan untuk menghasilkan siswa yang aktif, terampil, dan tidak tertinggal tentang literasi teknologi (Riswandi \& Hanum, 2013).

Pembelajaran dalam arti luas terdiri dari berbagai praktek yang memperlakukan siswa tidak hanya sebagai pelaku yang melaksanakan pembelajaran, tetapi juga sebagai pelaku tindakan kognitif yang didistribusikan antara pendidik dan siswa (Yaumi, 2011). Suatu proses dimana lingkungan suatu individu dengan sengaja dikelola untuk memungkinkan dia turut serta dalam tingkah laku tertentu dengan kondisi-kondisi khusus atau menghasilkan respons terhadap situasi tertentu dinamakan konsep dalam pembelajaran. Pembelajaran termasuk dalam bagian khusus pendidikan (Mustamin, 2013).

Matematika sebagai salah satu bidang studi yang mendukung perkembangan ilmu pengetahuan dan teknologi. Hanya saja sampai saat ini masih banyak siswa yang merasa matematika sebagai mata pelajaran yang tidak menyenangkan, sulit, bahkan menakutkan. Hal ini karena masih banyak siswa yang mengalami kesulitan ketika mengerjakan soal matematika (Mustamin, 2013). Matematika adalah pelajaran yang berhubungan dengan 
banyak konsep. Konsep-konsep dalam matematika saling berkaitan. Oleh karena itu siswa dituntut untuk bisa memahami materi dasar untuk lanjut ke materi berikutnya (Novitasari, 2016).

Berdasarkan kegiatan observasi awal yang dilakukan oleh peneliti maka diperoleh informasi dari hasil wawancara mengenai masalah-masalah yang dihadapi siswa, dalam proses belajar mengajar di kelas. Kebanyakan siswa masih tidak memiliki motivasi belajar yang baik khususnya pada mata pelajaran matematika, sehingga prestasi belajar matematika di kelas itu masih tergolong rendah. Penggunaan bahan ajar yang belum digunakan secara efektif oleh semua siswa. Kemudian, penggunaan buku ajar yang hanya mendominasi pada kecerdasan matematis-logis menyebabkan siswa mudah untuk bosan saat belajar, apalagi mereka yang tidak terlalu suka dengan matematika. Dalam pemahaman materi, siswa terlebih dahulu harus mengerjakan beberapa masalah bermodalkan soal matematika yang nantinya akan menjelaskan materi tersebut.

Salah satu usaha sebagai solusi yang ditawarkan peneliti untuk mendukung dan menunjang proses pembelajaran adalah dengan mengembangkan bahan ajar berbasis multiple intelligences. Bahan ajar ialah bahan yang berfungsi untuk membantu tenaga pengajar atau pendidik ketika melakukan kegiatan pembelajaran dalam kelas. Di sini bahan yang dimaksud boleh berbentuk tertulis maupun tidak tertulis (Majid, 2013). Dalam pendapat lain, fungsi dari bahan ajar ialah sebagai acuan bagi tenaga pengajar dalam mengarahkan seluruh aktivitas pembelajaran, bahan ajar juga menjadi substansi kompetensi, dan menjadi alat evaluasi untuk ketercapaian atau penguasaan hasil belajar siswa (Nurhidayati, Tayeb, \& Abbas, 2017). Pemilihan bahan ajar tertentu dapat sangat mempengaruhi proses pembelajaran sampai dengan prestasi belajar siswa.

Kurikulum 2013 menuntut kita menerapkan dan mewujudkan suasana belajar yang demokratis, kreatif, dan inovatif dalam proses pembelajaran, yaitu belajar yang melibatkan siswa belajar secara aktif, sehingga siswa dapat meningkatkan kemampuan berpikir kritis dengan hasil yang optimal yang disesuaikan dengan kecerdasan setiap siswa yang berbeda-beda atau biasa disebut dengan multiple intelligences. Konsep dari multi kecerdasan atau yang juga disebut multiple intelegences memusatkan pada keunikan setiap individu menemukan kelebihannya. Konsep ini mempercayai bahwa setiap individu pasti memiliki kelebihan meski hanya satu, jadi tidak ada individu yang bodoh. Teori Gardner ini menghargai setiap ciri khas yang menjadi keunikan seseorang, baik dari cara belajar yang tentu tidak sama, sejumlah model penilaian yang tentunya juga berbeda-beda, serta cara mengaktualisasi diri pada bidang yang tidak sama sesuai dengan kelebihan yang dimiliki (Arifin, 2017). Multi kecerdasan atau intelegensi ganda atau multiple intelligences adalah suatu kemampuan tertentu yang dimiliki oleh setiap individu yang bersifat independen ketika menyelesaikan masalah-masalah dalam proses pembelajaran. Teori Howard Gardner mampu membuat kegiatan belajar mengajar menjadi lebih variatif dan menarik dalam pembelajarannya, hal ini disebabkan karena setiap siswa akan memiliki kesempatan yang sama untuk mengembangkan kecerdasannya masing-masing. Howard Gardner juga mengatakan setiap anak memiliki kapasitas kecerdasan yang tidak sama, sehingga perlu ada penggunaan strategi multiple intelligences dalam proses pembelajaran agar potensi setiap siswa dapat dioptimalkan dan bisa menerima materi pelajaran dengan baik (Fransiska, Sardianto, \& Muslim, 2016). 
Sebuah proses yang jelas dan terarah yang digunakan ketika kegiatan mental seperti membujuk, menganalisis asumsi, memecahkan masalah, melakukan penelitian ilmiah, dan mengambil keputusan disebut cara berpikir kritis. Berpikir kritis ialah kemampuan dalam berpendapat yang dilakukan secara terorganisasi. Berpikir kritis ialah kemampuan dalam mengevaluasi pendapat orang lain secara sistematis (Johnson, 2007). Siswa dengan kemampuan berpikir kritis mampu menjawab permasalahan dengan baik, jelas, dan tepat. Siswa bisa menentukan/mempertimbangkan dengan hati-hati dan sengaja untuk menerima, menolak, atau menunda penerimaan suatu informasi (Sadiyyah, Gustiana, Panuluh, \& Sugiarni, 2019).

Penelitian ini didasarkan pada penelitian sebelumnya yang telah dilakukan oleh Aep Sunendar dan Erik Santoso (2020) yang mengatakan bahwa siswa antusias saat belajar matematika dengan sistem pembelajaran multiple intelligences, hasil analisisnya menunjukkan bahwa nilai rerata persepsi siswa terhadap pembelajaran berbasis kecerdasan majemuk berkategori baik. Selanjutnya penelitian yang dilakukan Umy Hasanatul Latifah dan Djamilah Bondan Widjajanti (2017) mengemukakan bahwa bahan ajar berbasis multiple intelligences ditinjau dari kemampuan memecahkan masalah, rasa ingin tahu, dan prestasi belajar siswa telah memenuhi kriteria valid, praktis, dan efektif. Lalu ada penelitian dari M. Asyrofi dan Iwan Junaedi (2016) yang mengemukakan bahwa faktor lain dalam meningkatkan kemampuan representasi matematis adalah tingkat kecerasan yakni kecerdasan visual spasial, kecerdasan bahasa, dan kecerdasan logis matematik.

Berdasarkan uraian latar belakang di atas, peneliti menganggap penting untuk mengembangkan bahan ajar berbasis multiple intelligences demi meningkatkan kemampuan berpikir kritis siswa. Penelitian ini bertujuan untuk mengetahui langkahlangkah pengembangan bahan ajar berbasis multiple intelligences, mengetahui kevalidan, kepraktisan, juga keefektifan bahan ajar berbasis multiple intelligences guna meningkatkan kemampuan berpikir kritis siswa kelas X SMAN 3 Wajo.

\section{METODE PENELITIAN}

Jenis penelitian dalam penelitian ini adalah penelitian dan pengembangan atau Research and Development ( $R \& D)$. Research and Development adalah jenis penelitian yang akan menghasilkan suatu produk tertentu, dimana produk ini akan menguji validitas, praktikalitas, dan efektifitas produk tersebut.

Research and Development (R\&D) ini mengacu pada model pengembangan 4D. Peneliti menggunakan model pengembangan 4D dengan alasan bahwa tahapan dari model ini sangat cocok dengan penelitian dan pengembangan bahan ajar yang akan dilakukan peneliti. Model pengembangan 4D terdiri atas 4 tahap utama, yaitu: fase pendefinisian (define), fase perancangan (design), fase pengembangan (develop), dan fase penyebaran (disseminate).

Subjek uji coba dalam penelitian ini adalah siswa kelas X SMAN 3 Wajo. Instrumen pengumpulan data yang digunakan dalam penelitian ini adalah lembar validasi ahli, lembar angket respons guru, angket respons siswa, lembar observasi kemampuan guru mengelola pembelajaran, lembar observasi aktivitas siswa, dan tes hasil belajar. 


\section{HASIL DAN PEMBAHASAN}

Pengembangan bahan ajar berbasis multiple intelligences sudah dilaksanakan menggunakan model pengembangan 4D yang terdiri dari empat tahap yaitu fase pendefinisian (Define), fase perancangan (Design), fase pengembangan (Develop), dan fase penyebaran (Disseminate). Penjelasan tahap-tahap pengembangan tersebut dijelaskan lebih lanjut sebagai berikut:

Tahap pertama yaitu tahap pendefinisian (Define). Di sini peneliti mendefinisikan dan menetapkan syarat-syarat pembelajaran dengan menganalisis tujuan dari batasan materi yang dikembangkan bahan ajarnya. Penelitian ini dilakukan pada kelas X SMAN 3 Wajo tahun pelajaran 2018/2019, materi pembelajaran yang diambil adalah trigonometri, dan kelas X MIA 1 sebagai subyek uji cobanya. Kelas X MIA 1 ini berjumlah 31 orang, terdiri dari 19 orang perempuan dan 12 orang laki-laki.

Analisis awal-akhir. Tahap ini penting untuk menganalisis guna mengidentifikasi berbagai masalah yang dihadapi oleh guru ketika proses pembelajaran matematika. Berdasarkan hasil observasi awal yang telah dilakukan peneliti, maka diperoleh bahwa proses pembelajaran masih terpusat pada guru (teacher centre). Guru cenderung lebih mendominasi pembelajaran sehingga siswa di kelas tidak aktif saat belajar. Hal ini dibuktikan dari banyaknya siswa yang kurang aktif saat proses pembelajaran berlangsung. Karena alasan di atas, peneliti memberikan solusi untuk membuat bahan ajar matematika berupa buku ajar yang berbasis mutliple intelligences pada materi trigonometri dengan tujuan untuk meningkatkan kemampuan berpikir kritis siswa di kelas X SMAN 3 Wajo yang kemudian akan digunakan dalam proses pembelajaran. Selanjutnya, analisis siswa. Pada tahap analisis siswa ini, peneliti menganalisis tentang bahasa dan latar belakang pemahaman (pengetahuan) siswa, dan tingkat kecerdasan kognitif siswa. Hasil analisis ini menunjukkan bahwa siswa di kelas X SMAN 3 Wajo memiliki pengetahuan matematika yang bervariasi, siswa sudah mempelajari beberapa materi penunjang trigonometri. Sementara bahasa yang digunakan siswa sebagian besar telah menggunakan bahasa Indonesia dalam kegiatan sehari-hari. Kemudian analisis tugas. Dari hasil observasi yang sudah dilakukan peneliti, maka diperoleh informasi bahwa beberapa tugas yang diberikan guru kepada siswa sudah disesuaikan dengan standar tugas dari buku ajar yang digunakan pada setiap pertemuan.

Analisis konsep. Kegiatan selanjutnya adalah mengidentifikasi, lalu merinci, kemudian menyusun materi -materi apa saja yang dipelajari oleh siswa kelas X SMAN 3 Wajo. Di sini materi yang dimaksud oleh peneliti adalah pokok bahasan trigonometri. Materi disusun secara sistematis dengan mengacu pada kurikulum 2013. Lalu perumusan tujuan pembelajaran. Pada tahap ini yang dilakukan peneliti adalah menjabarkan kompetensi dasar (KD) menjadi indikator pencapaian hasil belajar siswa. Indikator ini dibuat secara spesifik berdasarkan analisis tugas dan analisis materi.

Tahap selanjutnya adalah tahap perancangan (Design). Pada tahap ini, peneliti mulai merancang bahan ajar berbasis multiple intelligences dengan pokok bahasannya adalah trigonometri kelas X. Peneliti juga merancang desain dan perangkat penelitian yang akan digunakan dalam pembelajaran. Tahap kedua ini dimulai dengan penyusunan tes. Dari hasil analisis tugas dan konsep, maka dibuatlah kisi-kisi yang akan menjadi pedoman dalam menyusun tes yang akan dijadikan sebagai lembar penilaian tingkat penguasaan materi siswa untuk materi yang telah diajarkan. Tes ini disusun berdasarkan spesifikasi 
dari tujuan pembelajaran yang sebelumnya sudah divalidasi oleh ahli dan sudah valid. Kemudian disusun juga instrumen-instrumen lain yang menjadi tolak ukur dalam penilaian bahan ajar dari segi kelayakan, hingga mampu dikatakan valid, praktis, dan efektif. Selanjutnya pemilihan media. Media pembelajaran yang diperlukan dalam pelaksanaan pembelajaran berbasis multiple intelligences, media pembelajaran pada pokok bahasan trigonometri untuk kelas X SMAN 3 Wajo adalah bahan ajar yang terdiri dari: buku ajar, RPP,serta tes hasil belajar. Sementara penggaris, spidol, buku, papan tulis, pulpen, dan alat kebutuhan lain masuk dalam kategori alat bantu pembelajaran dalam penelitian ini. Kemudian memilih format pengembangan bahan ajar berbasis multiple intelligences . Adapun format dari bahan ajar ini terdiri dari format bahan ajar, format RPP, dan format tes hasil belajar. Format RPP ini disesuaikan dengan langkah-langkah pembelajaran matematika berbasis multiple intelligences. Aspek bahan ajar berbasis multiple intelligences dimasukkan juga ke dalam format RPP, dan untuk format tes hasil belajar serta format bahan ajar dibuat dengan rapi, teratur, dan berwarna juga terstruktur agar siswa tertarik dan termotivasi untuk belajar. Setelah memilih format untuk pembuatan bahan ajar, selanjutnya adalah melakukan perancangan tahap awal RPP. Berdasarkan standarisasi suatu proses proses pembelajaran itu dilihat dari perencanaan pembelajarannya yang memuat kegiatan penyusunan rencana pelaksanaan pembelajaran (RPP). Rencana pelaksanaan pembelajaran (RPP) merupakan suatu rencana kegiatan/proses pembelajaran yang memuat secara rinci suatu tema/materi pokok pelajaran tertentu berdasarkan isi dari silabus. Sebuah RPP setidaknya harus memuat tujuan pembelajaran, sintaks pembelajaran, dan penilaian pembelajaran sebagai komponen utama. Sementara komponen pelengkapnya mencakup: (1) identitas sekolah seperti nama pangkalan/sekolah, kelas/semester, mata pelajaran, serta alokasi waktu yang diperlukan, (2) kompetensi inti (KI), kompetensi dasar (KD), serta indikator pembelajaran, (3) materi pokok atau materi pelajaran, (5) model, pendekatan, dan metode pembelajaran, (6) sumber belajar, alat, serta media pembelajaran (Rindarti, 2018). RPP yang dibuat peneliti berjumlah 2 set yang memuat isi kegiatan untuk 2 pertemuan. Kemudian peneliti merancang isi dari bahan ajar yang akan dibuat. Kegiatan ini dilakukan dengan maksud agar salah satu kriteria pengembangan bahan ajar bisa terpenuhi yakni sebuah bahan ajar seharusnya mampu membantu siswa untuk mencapai tujuan dan kompetensi pembelajaran serta menarik. Oleh karenanya sebuah buku ajar harus dibuat berdasarkan kebutuhan dan sesuai dengan kompetensi yang harus dicapai oleh siswa. Di sini peneliti memutuskan untuk membuat bahan ajar dengan memakai pembelajaran yang berbasis multi kecerdasan untuk mata pelajaran matematika SMA di kelas X dengan materi trigonometri. Bahan ajar ini berbeda dengan bahan ajar yang lain, bahan ajar ini dirancang dan disusun dengan menarik, hal ini berdasarkan variasi warna dan gambar yang dipilih, penggunaan bahasa yang ringan sehingga mudah untuk siswa pahami ketika membaca dan mempelajarinya, bersifat sistematis mulai dari materi di setiap awal sub bab sehingga siswa mudah dalam memahami konsep ataupun memantapkan konsep sebab buku ajar ini bisa mempermudah dan membangun motivasi siswa untuk menyelesaikan soal.

Hal terakhir yang dilakukan peneliti di tahap Design adalah merancang tes hasil belajar. Tes hasil belajar ialah alat yang dijadikan bahan evaluasi untuk mengukur pencapaian siswa terhadap indikator pembelajaran yang sudah ditetapkan dalam RPP 
setelah siswa mengikuti proses pembelajaran (Purwanto, 2009). Peneliti terlebih dulu merancang kisi-kisi tes hasil belajar, jumlah butir soal tes, pedoman penskoran, dan kunci jawaban soal. Tes hasil belajar yang dibuat peneliti berupa tes tertulis dengan bentuk soalnya adalah essay, alokasi waktunya 90 menit, serta jumlah soalnya sebanyak 8 nomor.

Tahap ketiga ialah pengembangan (Develop). Tahap ini bertujuan menghasilkan suatu produk hingga produk tersebut layak digunakan dalam penelitian (Cahyadi, 2019), produk yang dimaksud adalah bahan ajar berbasis multiple intelligences yang sebelumnya harus divalidasi sebelum digunakan. Di tahap validasi semua perangkat instrumen penelitian dan bahan ajar dinilai oleh para validator. Validator akan mempertimbangkan kelayakan dari produk berupa bahan ajar. Bahan ajar ini sudah meliputi buku ajar, tes hasil belajar, dan rencana pelaksanaan pembelajaran (RPP).

Proses validasi ini berlangsung sebanyak 2 kali. Di tahap validasi pertama peneliti mengajukan bahan ajar rancangan awal yang berbasis multiple intelligences. Adapun masukan dan saran yang didapatkan dari para validator pada validasi pertama ini dapat dilihat pada tabel 1 .

Tabel 1. Saran untuk Perbaikan Prototype I oleh Validator

\begin{tabular}{ll}
\hline \multicolumn{1}{c}{ Aspek } & \multicolumn{1}{c}{ Saran Perbaikan } \\
\hline Bahan Ajar & $\begin{array}{l}\text { 1. Sampul yang digunakan masih perlu perbaikan dalam } \\
\text { hal kegrafisan }\end{array}$ \\
& $\begin{array}{l}\text { 2. Gambar yang terdapat dalam buku ajar harus lebih di } \\
\text { spesifikkan }\end{array}$ \\
& $\begin{array}{l}\text { 3. Materi yang ditampilkan dalam buku ajar terlihat } \\
\text { sangat penuh tiap halamannya }\end{array}$ \\
4. Bahasa yang digunakan harus jelas
\end{tabular}

Setelah mendapatkan saran perbaikan, peneliti kemudian merevisi bahan ajar yang telah dibuat. Lalu bahan ajar diajukan lagi untuk validasi kedua. Pada validasi kedua ini, peneliti juga mendapat beberapa saran lagi untuk perbaikan bahan ajar dan instrumen penelitian yang akan digunakan, saran yang diberikan ditampilkan pada tabel 2 . 
Tabel 2. Saran untuk Perbaikan Prototype II oleh Validator

\begin{tabular}{|c|c|}
\hline Aspek & Saran Perbaikan \\
\hline Bahan Ajar & Struktur isi buku ajar harus ditata lebih rapi lagi \\
\hline RPP & $\begin{array}{l}\text { Kegiatan siswa harus lebih jelas mengarah pada aspek } \\
\text { multiple intelligences yang mana }\end{array}$ \\
\hline Tes Hasil Belajar & $\begin{array}{l}\text { Pedoman penskoran pada THB harus lebih jelas pada } \\
\text { setiap aspek berpikir kritisnya. }\end{array}$ \\
\hline $\begin{array}{l}\text { Angket Respons } \\
\text { Siswa }\end{array}$ & $\begin{array}{l}\text { Penyataan pada angket harus mengarah kepada buku ajar } \\
\text { dan proses pembelajaran yang dibawakan }\end{array}$ \\
\hline
\end{tabular}

Dari validasi pertama dan kedua, para validator memberikan penilaian untuk bahan ajar dan instrumen penelitian dengan hasil: nilai rerata untuk validasi RPP berada pada kategori sangat valid dengan nilai 4,17, buku ajar juga berada pada kategori sangat valid dengan nilai rerata 4,21 , angket respons siswa dan guru masuk kategori sangat valid dengan masing-masing nilai reratanya sama-sama 4,33, lembar observasi kemampuan guru mengelola pembelajaran berkategori sangat valid dengan nilai 4,14, lembar observasi aktivitas siswa 4,31 berkategori sangat valid, serta tes hasil belajar yang juga berkategori sangat valid dengan nilai reratanya 4,22. Berdasarkan perolehan nilai tersebut, maka kevalidan dari bahan ajar dan instrumen penelitian yang telah dibuat sudah memenuhi kriteria valid dengan interval nilai yang berada antara $4 \leq M \leq 5$. Hal ini sejalan dengan pendapat Fitria, Mustami, \& Taufiq (2017) bahwa bahan ajar dikatakan valid apabila hasilnya sesuai dengan kriteria, dengan kata lain perolehan penilaian menunjukkan bahwa hasil tes mempunyai kesejajaran dengan kriteria yang sebelumnya sudah ditetapkan. Karena telah dinyatakan valid, maka perangkat bahan ajar dan instrumen penelitian sudah bisa digunakan dalam uji coba. Bahan ajar dan instrumen penelitian diuji cobakan kepada siswa di kelas X SMAN 3 Wajo. Uji coba ini dilakukan untuk menilai kepraktisan dan keefektifan dari penggunaan bahan ajar berbasis multi kecerdasan yang sudah dibuat. Kepraktisan dilakukan untuk mengetahui apakah bahan ajar yang sudah dikembangkan bias diterapkan dalam proses pembelajaran di kelas (Fitria, Mustami, \& Taufiq, 2017). Kriteria kepraktisan terpenuhi jika minimal 70\% siswa dan guru memberikan respons positif (Nurfiani, 2018). Dari uji coba ini, didapatkan perolehan nilai untuk angket respons siswa sebesar 80\%. Angket respons siswa diisi oleh 31 siswa di kelas X MIA 1 setelah seluruh rangkaian pembelajaran menggunakan bahan ajar berbasis multiple intelligences terlaksana atau selesai. Dari seluruh aspek penilaian yang ada pada lembar angket espon siswa, besar persentase siswa merespons adalah 81,25\%, angka ini berada dalam interval $70 \leq R S \leq 85 \%$, interval ini berada pada kategori positif.

Data pendukung lain untuk melihat kepraktisan bahan ajar ini adalah dengan melihat hasil angket respons guru. Dari angket ini guru akan memberikan penilaian tentang bahan ajar saat digunakan dalam kegiatan belajar mengajar. Guru telah memberikan penilaian dengan persentasinya sebesar 92,50\%. Nilai ini berada dalam interval penilaian $85 \leq R S \leq 100$ dengan kategorinya adalah sangat positif. Karena hasil analisis angket respons siswa mendapatkan kategori positif, dan angket respons guru mendapatkan kategori sangat positif, maka dapat diambil keputusan bahwa penggunaan bahan ajar berbasis multiple intelligences sudah praktis. Kriteria lain yang harus dipenuhi selain valid dan praktis adalah keefektifan dari penggunaan bahan ajar. Penilaian ini akan melihat apakah penggunaan bahan ajar berbasis multiple intelligences memberi perubahan 
dalam kegiatan pembelajaran atau tidak. Hal ini sesuai dengan pendapat Trianto (2009) yang mengemukakan bahwa suatu pembelajaran efektif apabila siswa meluangkan lebih banyak waktunya untuk belajar dan besarnya antusias siswa untuk mengerjakan tugas. Penilaian ini dilihat dari hasil analisis lembar pengelolaan pembelajaran, pengamatan aktivitas siswa, dan tes hasil belajar. Lembar pengelolaan pembelajaran bertujuan untuk mengetahui sejauh mana guru bisa mengelola kegiatan pembelajaran di kelas saat menggunakan buku ajar yang peneliti kembangkan. Dari instrumen ini hasil yang didapatkan adalah rata-rata nilai sebesar 4,28. Nilai ini berada pada interval 3,50 $\leq$ $T K G \leq 4,50$, yang artinya penilaian kemampuan guru berada pada kategori baik.

Lembar pengamatan aktivitas siswa bertujuan untuk melihat segala aktivitas yang dilakukan siswa selama kegiatan pembelajaran, aktivitas yang dimaksud tentu dikaitkan ketika siswa belajar di kelas menggunakan bahan ajar berbasis multiple intelligences, apakah siswa akan aktif dan lebih mendominasi daripada guru atau tidak. Perolehan hasil analisis yang didapatkan, terlihat bahwa persentase nilai reratanya adalah $64,53 \%$. Nilai ini berkategori baik karena terdapat dalam interval nilai $60 \% \leq P<80 \%$. Untuk tes hasil belajar itu digunakan untuk melihat kemajuan dari pemahaman siswa setelah menggunakan bahan ajar berbasis multiple intelligences dalam pembelajarannya. Tes ini diberikan kepada 31 siswa diakhir pembelajaran atau setelah semua pertemuan pembelajaran selesai. Hasil tesnya menunjukkan bahwa tidak ada siswa yang berada dalam kategori rendah, sedangkan siswa dengan kategori sedang sebanyak 19,35\%, siswa berkategori tinggi sebesar 64,52\%, dan untuk siswa yang hasil tesnya berkategori sangat tinggi sebesar 16,13\%. Dari ketiga instrumen yang digunakan untuk menilai keefektifan bahan ajar secara keseluruhan bisa ditarik kesimpulan bahwa bahan ajar berbasis multiple intelligences juga telah efektif dalam penggunaannya. Hasil ini sejalan dengan hasil penelitian Mualdin dan Edy (2015) yang menunjukkan bahwa apabila dalam proses pembelajaran pendidik yaitu guru menggunakan media atau bahan ajar yang mempunyai tingkat keefektifan tinggi, maka itu akan berdampak baik bagi prestasi belajar siswa.

Tahap terakhir dari model 4D adalah penyebaran (Disseminate). Tujuan tahapan ini adalah untuk menyebarkan produk yang sudah dikembangkan secara luas di lapangan (Kurniawan \& Dewi, 2017). Di tahap ini peneliti seharusnya mensosialisasikan atau mendistribusikan atau menyebarkan bahan ajar yang telah dikembangkan kepada beberapa guru dan siswa. Namun karena adanya keterbatasan waktu, maka peneliti hanya mendistribusikan bahan ajar ini kepada beberapa guru matematika SMA dari berbagai sekolah. Pendistribusian ini dilakukan dengan harapan agar bahan ajar berbasis multiple intelligences yang sudah dibuat bisa dikenal secara luas sebagai karya dari mahasiswa Pendidikan Matematika Universitas Islam Negeri (UIN) Alauddin Makassar.

\section{SIMPULAN}

Berdasarkan hasil dan pembahasan, diperoleh bahwa (1) Buku ajar berbasis multiple intelligences dikembangkan dengan menggunakan model pengembangan 4D (define, design, development, dan disseminate), (2) Bahan ajar valid dengan kategori sangat valid, (3) Bahan ajar praktis pada kategori positif dan persentase rerata respons guru pada kategori sangat positif, (4) bahan ajar efektif karena rerata kemampuan guru dalam mengelola pembelajaran pada kategori baik, persentase rata-rata aktivitas pada kategori baik, dan persentase ketuntasan belajar siswa berada pada kategori tinggi sehingga 
pengembangan bahan ajar berbasis multiple intelligences pada materi trigonometri di kelas X SMAN 3 Wajo memenuhi kriteria kevalidan, kepraktisan, dan keefektifan. Hal ini sejalan dengan apa yang diharapkan dari pengembangan bahan ajar berbasis multiple intelligences yang telah dipaparkan pada bagian pendahuluan. Untuk prospek pengembangan penelitian berikutnya, peneliti menyarankan untuk mengembangkan bahan ajar dari materi-materi lain dan menyandingkan pengembangan bahan ajar dengan model pembelajaran.

\section{DAFTAR PUSTAKA}

Arifin, H. (2017). Konsep multiple intelligence system pada Sekolah Menengah Pertama AlWashlyah 8 Medan dalam perspektif Islam. Edutech Jurnal Ilmu Pendidikan Dan Ilmu Sosial. https://doi.org/https://doi.org/10.30596/edutech.v3i1.986

Cahyadi, R. A. H. (2019). Pengembangan bahan ajar berbasis ADDIE model. Halaqa: Islamic Education Journal. https://doi.org/10.21070/halaqa.v3i1.2124

Fitria, A. D., Mustami, M. K., \& Taufiq, A. U. (2017). Pengembangan media gambar berbasis potensi lokal pada pembelajaran materi keanekaragaman hayati di kelas X SMA 1 Pitu Raise Kab. Sidrap. AULADUNA: Jurnal Pendidikan Dasar Islam, 4(2). https://doi.org/https://doi.org/10.24252/auladuna.v4i2a2.2017

Fransiska, Y., Ms, S., \& Muslim, M. (2016). Pengembangan lembar kerja siswa berbasis kecerdaasan majemuk untuk pembelajaran fisika kelas $\mathrm{X}$ pada materi elastisitas. Inovasi dan Pembelajaran Fisika, 1-7.

Johnson, E. B. (2007). Contextual teaching and learning menjadikan kegiatan belajar mengajar mengasyikkan dan bermakna. Bandung: MLC.

Kurniawan, D., \& Dewi, S. V. (2017). Pengembangan perangkat pembelajaran dengan media screencast-o-matic mata kuliah kalkulus 2 menggunakan model 4-D Thiagarajan. Jurnal Siliwangi, http://jurnal.unsil.ac.id/index.php/jspendidikan/article/view/193

Majid, A. (2013). Perencanaan pembelajaran: mengembangkan standar kompetensi guru. Bandung: Rosda.

Mustamin, S. H. (2013). Psikologi pembelajaran matematika. Alauddin Press.

Novitasari, D. (2016). Pengaruh penggunaan multimedia interaktif terhadap kemampuan pemahaman konsep matematika siswa. Jurnal Pendidikan Matematika Dan Matematika. https://doi.org/https://doi.org/10.24853/fbc.2.2.8-18

Nurfiani. (2018). Pengembangan buku ajar berbasis model pembelajaran kuantum (quantum) materi eksponen kelas X MA DDI Pattojo [UIN Alauddin Makassar]. http://repositori.uin-alauddin.ac.id/id/eprint/11673

Nurhidayati, S., Tayeb, T., \& Abbas, B. (2017). Pengembangan bahan ajar matematika berbasis masalah untuk memfasilitasi pencapaian kemampuan penalaran pada pokok bahasan perbandingan kelas VII MTsN Model Makassar. MaPan Jurnal Matematika dan Pembelajaran. https://doi.org/https://doi.org/10.24252/mapan.v5n2a6

Purwanto. (2009). Evaluasi hasil belajar. Yogyakarta: Pustaka Pelajar.

Rindarti, E. (2018). Peningkatan kompetensi guru dalam mengembangkan RPP kurikulum 2013 revisi 2017 melalui pendampingan berkelanjutan di MA Binaan kota Jakarta Pusat tahun pelajaran 2017/2018. Jurnal Penelitian Kebijakan Pendidikan, 11(2). https://doi.org/https://doi.org/10.24832/jpkp.v11i2.221 
Riswandi, B. A., \& Hanum, F. F. (2013). Peningkatan kualitas siswa terampil IPTEK dengan edukasi komputer bagi siswa SD di dusun Wonolelo. Jurnal Inovasi Dan Kewirausahaan.

Sadiyyah, R., Gustiana, M., Panuluh, S. D., \& Sugiarni, R. (2019). Pengembangan Lembar Kerja Siswa (LKS) dengan pendekatan inkuiri terbimbing berbasis mobile learning untuk mengoptimalkan kemampuan berpikir kritis matematis. Jurnal Prisma. https://doi.org/https://doi.org/10.35194/jp.v8i1.616

Sadulloh, U. (2015). Pengantar filsafat pendidikan. Bandung: Alfabeta.

Sagala, H. S. (2013). Administrasi pendidikan kontemporer. Bandung: Alfabeta.

Sinurat, M., Syahputra, E., \& Rajagukguk, W. (2015). Pengembangan media pembelajaran matematika berbantuan program flash untuk meningkatkan kemampuan matematik siswa SMP. Jurnal Pendidikan Tabularasa, 12(2). https://doi.org/https://doi.org/10.24114/jt.v12i2.3247

Sundayana, R. (2013). Media pembelajaran matematika: untuk guru, calon guru, orang tua, dan para pencinta matematika. Bandung: Alfabeta.

Trianto. (2009). Mendesain model pembelajaran inovatif-progresif (Cet. 1). Surabaya: Kencana Prenata Media Group.

Yaumi, M. (2011). Pembelajaran berbasis multiple intelligence. Makassar: Alfabeta. 